\title{
NOTAS
}

\section{Resurrección del Cristiano Errante}

En el número 73 de la Revista Iberoumericana, oct-dic. 1970, pp. 613-27, se resucitó al "Cristiano errante", Antonio José de Irisarri, con la consabida agresividad que le desmiente el nombre: errante, sí, pero ¿cristiano? Se trata del rótulo "novela" que se le niega en mi Historia critica de la novela guatemalteca (Guatemala, 1960).

Se pregunta: "¿por qué tanto empeño en buscar categorías para obras literarias?" El título de mi libro es Historia crítica de la novela guatemalteca; no es Historia critica de la literatura guatemalteca. El hecho de que un libro no sea novela no rebaja en absoluto su valor literario. Cito de las conclusiones de mi libro: "Aunque una obra debe ser juzgada por sus propios méritos sin tener en cuenta si cumple o no con los requisitos de cierto género, muchos libros guatemaltecos descienden de valor por causa de la confusión de géneros, en tanto que a otros no se les ha apreciado lo bastante precisamente por su dudosa identidad" (p. 321). Las Memorias de Fray Servando Teresa de Mier, Facundo de Sarmiento y El águila y la serpiente de Martín Luis Guzmán son obras importantes dentro de la literatura hispanoamericana sin ser novelas.

Precisar un concepto de la novela tiene una importancia especial en la literatura guatemalteca donde abundan las obras híbridas: El cristiano errante, Don Bonifacio (en verso) de José Milla, El hombre que parecía un caballo (16 págs.) de Arévalo Martínez, Weekend en Guatemala (¿colección de cuentos o novela?) de Miguel Angel Asturias y otras muchas.

La definición de "novela" que utilicé en mi libro se basa en parte en la definición del Diccionario de la Real Academia Española a la cual agregué ciertas frases para distinguir la novela tanto del cuento 
como de la crónica y de las memorias... "teniendo en cuenta, desde luego, la arbitrariedad de las definiciones" (p. 7).

Las novelas citadas en el artículo aludido, Ulysses, Tristram Sbandy y Paradiso, son novelas sin lugar a dudas y cabrían muy bien dentro de mi definición.

Si el Cristiano errante se siente tan emparentado con el Dogma socialista de Echeverría, con la Investigación sobre la influencia de la conquista y del sistema de los españoles en Cbile de Bello, con la Sociabilidad cbilena de Francisco Bilbao, con la Influencia social de la conquista y del sistema colonial de los españoles en Cbile de Lastartia y con Facundo de Sarmiento, ¿por qué se alborota tanto cuando no se le concede el título errado de novela?

SEYMOUR MENTON

University of California, Irvine 